\title{
Economic Viability of Fish Smoking and Marketing: Evidence from Ibi, Taraba State, Nigeria
}

\author{
G.O. Onogwu ${ }^{1 *}$ Asogah Solomon Edoh ${ }^{2}$ O.G. Akise ${ }^{3}$ \\ 1. Department of Agricultural Economics and Extension Services, Federal University Wukari, 200 \\ Katsina-Ala Road, P.M.B 1020, Wukari, Taraba State, Nigeria
}

2. Department of Agricultural Economics and Extension Services, Federal University Wukari, 200 Katsina-Ala Road, P.M.B 1020, Wukari, Taraba State, Nigeria

3. Department of Fisheries and Aquaculture, Nigeria Maritime University Okerenkoko, Delta State, Nigeria

* E-mail of the corresponding author: ngwugodwin@gmail.com

\begin{abstract}
This study explored the effects of socio-economic profile of the marketers and determined the economic viability of fish smoking and marketing in Ibi, Taraba State, Nigeria. A multistage random sampling technique was employed to illicit response from 80 respondents for the study. Data collection were through structured questionnaire. Descriptive statistics, regression analysis, marketing margin and net marketing margin estimation procedures among others, were used to determine the values of the profitability measures that infer the significant influential variables economic viability of fish smoking and marketing venture. The frequency distribution of respondents according to: - age, gender, marital status, household size, major occupation, educational level, marketing experience and preservation method adopted were constructed and detailed results presented in section 4. Marketing margin obtained was $23.43 \%$, with a net marketing margin of $13.77 \%$, resulting from a total gross and net revenue of smoked fish sales of N1, 378,889 and N810, 580, respectively. The smoked fish selling price, unsmoked fish purchasing price and total smoked fish cost stood at N5,886,079, N4,507,190 and N5,075,449, respectively. The fish smoking efficiency of 3.06 and smoked fish marketing efficiency of 2.43 indicates that the dealers make a net return of 3.06 times per N1.00 invested in fish smoking which sells 2.43 times faster than unsmoked type. Hence, a clear indication that fish smoking and marketing is economically viable in the area studied. It is recommended that national market development coordinating should be put in place to ensure the adoption of standard weight and measure for fish smoking and marketing in the area; cost saving transportation and smoking service facilities should be sustained by private individuals and corporate groups alike to improve efficiency of venture by dealers; capacity building for agricultural extension officers and enumerators on market information service (MIS) should be intensified by Government.
\end{abstract}

Keywords: Economic viability; Marketing Margin; Net Marketing margin; net return, Fish smoking and marketing.

DOI: $10.7176 / \mathrm{JMCR} / 52-06$

\section{Nigeria Natural Resource Endowment for Fisheries and Aquaculture}

Nigeria is blessed with abundance of both fresh and marine water fish resources. Information retrieved from https://www.meat-machinery.com/meat-processing-insight/Nigerian-smoked-fish-market-potential.html indicate that there are estimated 12,478,818 hectares of inland waters and some 741,509 hectares of brackish waters, most of which are suitable for aquaculture. It further explained that about 5,476 hectares of these waters are employed for fishery at present. In addition, it narrated that Nigeria has 200 nautical mile Exclusive Economic Zone (EEZ) that spans $853 \mathrm{~km}$ of coastline and covers $192,000 \mathrm{~km} 2$ areas. And clarified that fish supply of Nigeria is from four major sources namely artisanal fisheries, industrial trawlers, aquaculture and important frozen fish; with the Niger Delta contributing more than 50\% of the entire domestic Nigeria fish Supply.

Fish is an important source of protein intake of many people, especially the people in developing countries. In Nigeria, about $41 \%$ of the total animal protein intake is obtained from fish products. And it is reported that fish is a major source of animal protein and an essential food item for Nigeria because, it is relatively cheaper than meat. The total demand for fish and fish product is higher in Nigeria than in many other West African Countries (https://www.meat-machinery.com/meat-processing-insight/Nigerian-smoked-fish-market-potential.html). 


\subsection{Fish Smoking as an Important Preservation Method in Nigeria}

Marketing comprises all strategies and ways through which a product of agricultural industry are transferred from where they are produced to the ultimate consumers (Subba et al, 2004). Through marketing processes, the economic process of exchanging goods (fish) and services (smoking) between the producer, marketers and the consumers cum the determination of their values in terms of money prices is ensured. The process of fish marketing is a very delicate one, if the quality and nutritive value is to be maintained to the highest possible level. It includes processing, storage, preservation, transportation, wholesaling, and retailing. Based on these facts, efficient marketing would be a way forward for management of the available resources given the high rate of produce deterioration. Moreover, processing and marketing activities provide the greatest opportunities for employment within the aquaculture industry (Okoronkwo, 2016). Market for fish is therefore perceived as a place where title of goods and or services are exchanged at a given time and price from producers to smoked fish marketers and from smoked fish marketers to retailer and to the final consumers, given the prevailing marketing channel. Exchange of titles in fish marketing requires at least two individuals here referred to as buyers and sellers that have to bargain and agree for transaction on the good and or service to occur, leading to a higher level of satisfaction by each individual. For these key marketing functions to be actualized, the performance of some other major marketing functions such as assembling, grading, transportation, fire-drying (processing), storing, sales etc. for and by middlemen of interest, mostly smoked fish marketers and or retailers have to be fulfilled. Fish marketing like marketing of other goods and services has economic value because it gives form, time, place, utility to products and services (Benjamin and Victoria, 2012).

\subsection{Urbanization Effects on Marketing of Fish}

The marketing of fish has steadily changed due to urbanization. Thus, as the process of urbanization progresses in Nigeria, an increasing share of national fish consumption takes place at locations other than where fish is produced (Umoniyang, 2014). Before increased urbanization and population, fish produced were locally and domestically consumed. With increasing urbanization and population drift to urban areas, the distance between fish producers and consumers has increased and fish marketing has become very important. Smoking of fish or sun drying serves the purpose of preserving and maintaining the quality, though both fresh and dried fish have to be transported to the urban center to actualize sales. Sometimes, middle men move into the production areas to purchase and transport items to urban areas for sales.

\subsubsection{The Problems of Fish Marketing}

The developing nature of Nigerian economy imposes a lot of challenges on the marketing of agricultural goods and services, especially products like smoked-fish. It has been argued that agricultural marketing is inefficient due to fragile, poor storage, seasonality, perishability nature of the produce resulting to high rate of spoilage and unaffordable prices and vicious cycle of poverty on the part of small scale producers cum marketers. The affordable preservative measure adopted by the marketers that ensured longer shelve life of the product is, but smoking/fire-drying. By fire-drying, the weight of the fish is reduced through loss of all water and some fat contents. This of course is welcome by most of the smoked-fish consumers who purchase and store them for future use. The major research question is; how do the efforts of smoking/fire-drying (value addition) that results to weight loss in fish transmit to an increased price value and margin for the marketer, knowing so well that production in agriculture or otherwise are fulfilled with marketing to actualize the profit-making purpose in terms of price values.

Fish is highly perishable in nature, with post-harvest loss accounting for over $25 \%$ of the total catch or harvest in the country (Eyo, 2008). To cater for the protein and food security need of the teeming population of the country, the post-harvest losses in relation to fish needs of the country at large should be addressed. This can be achieved through efficient marketing system aimed at ensuring quality conveyance of fish from the initial place of production to the ultimate consumers. The post-harvest efforts which primarily involves processing, storage and preservation is in the state of depression (Ikenwa, 2016). More so, fishery products are highly fragile and the type of physico-chemical techniques used in processing and preservation has a large role to play in targeting the markets and prices. In Nigeria, the techniques used in fish preservation (smoking/fire-drying, salting, and or sun drying) if not committedly undertaken compromises quality of the products to even meet the local and or international markets standard.

As a perishable commodity, transportation of fishery products from point of production to the market at a rightful time is very important to improve net returns and to record minimal wastage. Nigerian marketers are faced with the problems of processing and preserving fish in a condition that gives the optimal satisfaction to consumers. After drying, they further face the problems of inadequate handling and transportation, moulding and 
smashing (Nwankwo and Ogalue 2000). This research work aims at addressing the following research questions:

(i) What are the socio-economic characteristics of the small-scale fish smoking and marketing operating in the study area?

(ii) What constraints/problems do fish marketers face in the study area?

(iii) What are the levels of value added to the smoked-fish?

(iv) Does the envisaged value addition translate to profitability for the fish marketers?

\subsection{Study Objectives and Hypothesis}

The broad objective of the study is to determine the value added and profitability of marketing smoked-fish in Ibi Local Government Area of Taraba State, Nigeria.

The specific objectives are to:-

(i) Examine the socio-economic profile of the small-scale smoked-fish marketers in the study area.

(ii) Examine the business of small-scale fish smoking and marketing in the study area.

(iii) Determine the effects of socio-economic profiles on the income of the marketers

(iv) Estimate the value additions and smoking efficiency made possible by the efforts of marketers to improve shelf life.

(v) Determine the gross margin and marketing efficiency of fish smoking and marketing among dealers.

The hypothesis tested is:

Socio-economic characteristics of the fish smoker-marketers do not significantly influence their income.

\section{$1.4 \quad$ Justification}

The need to investigate the value addition and profitability of small scale fish smoking and marketing in Ibi Local Government Area of Taraba state cannot be over emphasized. More so there abound so many school leavers that could venture into value addition through fish smoking and marketing given the abundance of fish catching hobbies of the populace, but for the fear of the economic viability of the business. This study determined the gross margin cum net return on small-scale fish smoking and marketing. In this way, unemployed youths may take advantage of the ever available fish catch and market to engage in a viable value addition and marketing of smoked-fish. This research work serves as a vital material to those who may want to carry out further research work in this regard in addition to filling these gaps in knowledge.

\section{Problems Faced by Fish Marketers in Nigeria}

Fish marketing in Nigeria is faced by a lot of problems. Many authors have researched into this area and reported their findings. Akinola (2015) reported from a study in Ogun state that the major problem with marketing is high cost of preserving the fishes. He noted that $62 \%$ of his respondents (marketers) were confronted by the preserving problem. Other problems are huge initial expense, purchase price instability, and inconsistent and high cost of transportation. Nwabueze (2010) reported that seasonality, scarcity, means of preservation, poor means of transportation and use of badly-shaped containers were the main problems of fresh fish marketing in the area.

Another study carried in Enugu South Area of Enugu State identified problems found among women marketers of agricultural produce to be inadequate processing skill, produce deterioration and lack of storage facilities (Eze, et. al., 2010). They reported that specific issues which loaded high and amplified inadequate processing skill included, inadequate processing equipment $(0.44)$, long distance to processing centers $(0.45)$ and inadequate packaging information (0.55). Others were poor technical knowhow (0.42), and poor technical extension services (0.37). They further underscored the challenge of lack of storage facilities as a major factor in agricultural produce marketing which they reported are loaded under the specific issues: high cost of shops (0.41), inadequate storage facilities (0.47), poor performance measure (0.34) and low equity capital (0.40).

Abah et' al (2013) stated problems that militate against fish marketing in a research carried in Lafia Local Government Area of Nasarawa state. They are combination of inadequate funds, transportation, storage, and quality. Inadequate funds is a major problems faced by both wholesaler and retailers, with smoked fish marketers ranking the highest and that will affect the quantity of fish required by them. The lack of good storage facilities is major concern of retailers whereas transportation ranks higher with smoked fish marketers. This is obvious considering the fact that retailers usually sell in small quantity at a point in time, hence good storage facilities would most likely be their concern. Smoked fish marketers on the other hand, usually travel far and wide to 
procure the commodity and so have to contend with the rising transport fares.

\subsection{Fish Demand and Supply in Nigeria}

The Nigeria fisheries sub sector contributes about 3-4 percent to the country's annual GDP and is an important contributor to the population's nutritional requirements, constituting about 50 percent of animal protein intake. In addition, the sub-sector generates employment and income for a significant number of artisanal fishermen and small traders. Although captured fisheries have now been declining, Nigeria has a big potential in both marine and fresh water fisheries including aquaculture. In spite of this high potential, domestic fish production still falls far below the total demand, which was estimated at 2.2 million metric tons per year in 2008 . As a result, the country imports about 60 percent of the fish consumed. To reduce the level of fish imports, aquaculture has been selected as one of the priority value chains targeted for development in the next four years. The National Aquaculture Strategy Plan has been finalized with the assistance of FAO to guide support for the value chain (FAO, 2013).

According to the UN FAO biannual report titled "The State of World Fisheries and Aquaculture 2016", over exploitation of the planet's fish has more than tripled since the 1970s with 40 percent of popular species such as tuna now caught unsustainably. It is important to note that despite the sustainable limit and increase in production attained at the global level, countries like Nigeria, suffers from low supply because of the impact of illegal, unreported, and unregulated fishing. Nigeria's per capita fish consumption of $11 \mathrm{~kg}$ is generally considered low, despite its abundant aquatic natural resources. The report further stated that the country relies heavily on importation of fish to bridge the deficit in production. Nigeria's total fish supply stood at about $1,160,000$ tons in 2004 . The major sources are imports (56\%) coastal; brackish-water and inland fishery $(37.6 \%)$; industrial trawl fishery (2.6\%); and aquaculture (3.8\%). Total domestic fish production in 2007 stood at an estimated 600,000 tons, while importation is estimated at over 700,000tons. Nigeria has to import about 700,000 tons of fish valued at about US \$500 million annually.

According to report on fishery in Nigeria by Ministry of Agriculture (2013), Nigeria's demand for fish in 2010 was projected at 1.89 million tons. However, actual production was 800,000tons. The fish supply gap deficit was over 1 million tons. Considering that the population growth rate of Nigeria is $3 \%$, the fish supply gap deficit is expected to continuously increase. Current global average annual consumption is about $16.0 \mathrm{~kg} / \mathrm{year}$ although it is $13.5 \mathrm{~kg}$ /year. If the Nigeria targets the amount, the total demand will be $20 \%$ more than the forecasted demand the gap will be some 2 million Tons.

Nigeria with the per capita fish consumption of $13.5 \mathrm{~kg}$ has recorded a projected fish demand of $1,430,000$ tons with the projected domestic production of 467,098 tons having the deficit in supply of 962,902 tons in the year 2000. The demand in 2010 was $1,890,000$ tons and a supply of 634,560 with deficit of $1,255,440$ tons. In 2015 the demand has increased drastically to $2,175,000$ tons and the domestic supply was 730,248 tons having deficit in supply of 1,444,752 tons (Naoki, 2013). With the record at hand, the supply is short of the demand of the country thereby requiring an urgent effort to increase the domestic aquaculture production to meet the demand for fish in the country.

\subsection{Fish Marketing Channels}

The fish smoking and marketing are involved in a set of practices or activities necessary to transfer the ownership of goods from the point of production cum processing to the point of consumption. In this way smoked-fish get to the end-user (the consumer). These practices and or activities carried out by the fish smoking and marketing pass along or through a specified route or medium which has been customized here as a distribution channel. The marketing channel(s) describes the existence of a trade medium for communication or the passage of smoked-fish that bridge the access gap between fish producers, marketers and consumers in the area under survey. In these regards, marketing of smoked-fish in the study area provides a social process by which individuals and groups obtain what they need and want through creating and exchanging products and value with others. Comparisons of marketing channels or paths through which goods or materials could move from producers to users make it easy to understand how the term 'middleman' came into being as a way to explain product flows (Lou et' al, 2014). A marketing channel operates as a team, sharing resources and risks to move products and resources from their point of origin to their point of final consumption. According to Subba et' al (2004), agricultural commodities move from the farmers to consumers over time and space, and the movement is possible through various market intermediaries that operate in the marketing system. They further stated that marketing channels differ from commodity to commodity; implying that the marketing channel for smoked-fish differ from that of eggs. Furthermore, they opined that marketing channel strategically links producers to buyers, influences the firm's pricing strategy, affect product strategy through branding among other 
roles. Based on the level of relationship between the producer of a product and the ultimate consumer, there are four types of the marketing channels:

The Producer $\rightarrow$ Customer channel: This is where the producer sells goods or provides the service directly to the consumer with no involvement with a middleman such as a wholesaler, a retailer, an agent, or a reseller. Producer $\rightarrow$ Retailer $\rightarrow$ Consumer: Here the retailer buys the product from the producer and sell them directly to the consumer. Producer $\rightarrow$ Wholesaler/Distributor $\rightarrow$ Customer. In this channel, transfer of ownership pass through the wholesaler from the producer to the final consumer, the wholesaler buy product from producer and sell to the consumer and the price of acquisition of product is cheap due to the consumer buying in bulk from the wholesaler. Producer $\rightarrow$ Agent/Broker $\rightarrow$ Wholesaler or Retailer $\rightarrow$ Customer. This distribution channel involves more than one intermediary before the product gets into the hands of the consumer. This middleman, known as the agent, assists with the negotiation between the producer and the seller. Agents come into play when the producers need to get their product into the market as quickly as possible. This happens mostly when the item is perishable and has to get to the market fresh before it starts to rot. At times, the agent would link the retailers directly to the goods, or take an alternate route through the wholesaler who would link retailer and then finally to the consumer.

\subsection{Marketing Margin}

Marketing margin is the difference between the price received by producers and paid by consumers (Tomek and Robinson, 1990). Put differently, marketing margin is the difference between what a company pays for the product and what it charges for the product. Besides, Cramer and Jensen (1982), opined that marketing margin is the percentage of the final weighted averages selling price taken by each stage of the marketing chain. Again, (Mendoza, 1995) stated that the total marketing margin is the difference between what the consumer pays and what the producer/farmer receives for his product. All these suggest that it is the difference between retail price and farm price.

\subsection{Net Marketing Margin}

Net profit margin, or net margin, is equal to net income or profits divided by total revenue. This measures how much profit each Naira of sales generates. Net profit margin is the ratio of net profits or net income to revenues for a company, business segment or product. Net profit margin, or net margin, is equal to net income or profits divided by total revenue and represents how much profit each dollar of sales generates. Net profit margin is the ratio of net profits or net income to revenues for a company, business segment or product. Net profit margin is typically expressed as a percentage but can also be represented in decimal form. The net profit margin illustrates how much of each Naira collected by a company as revenue translates into profit. The term "net profits" is equivalent to "net income" on the income statement and one can use the terms interchangeably. Most commonly, investors will refer to net profit margin as the "net margin" and describe it as "net income" divided by total sales instead of using the term "net profits" (https://www.investopedia.com/terms/n/net_margin.asp). The net margin (percentage or amount) should always be positive. A positive net margin signals that the financial institution or farm firm is generating sufficient income from its assets to cover the cost of funds paid on savings and products in addition to on other sources of funds, as well as its operating expenses. A negative net margin means the opposite, that the institution or farm firm is not generating enough income to cover costs (https://www.woccu.org/documents/Tool6). It means the percentage of revenue that remains after all operating expenses have been deducted.

\subsection{Marketing Efficiency}

The Efficient Market Hypothesis (EMH) is an investment theory whereby share prices reflect all information and consistent alpha generation is impossible. Theoretically, neither technical nor fundamental analysis can produce risk-adjusted excess returns, or alpha, consistently and only inside information can result in outsized risk-adjusted returns. According to the EMH, stocks always trade at their fair value on stock exchanges, making it impossible for investors to either purchase undervalued stocks or sell stocks for inflated prices. As such, it should be impossible to outperform the overall market through expert stock selection or market timing, and the only way an investor can possibly obtain higher returns is by purchasing riskier investments (https:/www.investopedia.com/terms/e/efficientmarkethypothesis.asp). The Calkin's index of marketing efficiency is estimated using the following formula. Marketing efficiency $=1+$ Sum of profit or margin/Sum of marketing cost. The lower the value of the index, higher would be the efficiency (http://ecoursesonline.iasri.res.in/mod/page/view.php?id=16979). Besides, marketing efficiency can be referred to as a measure of the extent to which an investment is profitable. As goods are supposed to move from producers to the consumers at the lowest possible cost, the movement of these goods at lowest possible price 
subject to adequate provision of desired services to consumers can be called efficient marketing.

\subsection{Marketing Functions}

Marketing functions facilitates the transfer of ownership of the products from the producers to the consumers. In the transfer of ownership, several activities are performed. Now marketing function can be identified as a single activity, which facilitates the movement of the product from the point of its production till it reaches the ultimate consumer (Subba et' al, 2004). Marketing functions encompasses the broad concept of concentration and dispersion. That is the collection of goods produced from various production units in a center and the distribution of the goods among the ultimate consumers. Marketing functions are classified based on different concepts. Subba et, al (2004) outlined four different marketing functions as function of transfer of ownership( selling, buying, demand creation and price determination), function of physical movement ( transportation and storage), and facilitating functions (market financing, risk bearing and market information).

\subsection{Analytical Framework}

This study makes use of net profit margin analysis, adopting from Nsikan et' al (2014) work on the marketing and profitability among captured fish traders in south-south Nigeria using marketing margin, marketing efficiency, and gross margin analysis as modelled. The gross margin and marketing efficiency models adopted in this study are as expressed in methodology.

\section{The Study Area}

Ibi Local Government Area of Taraba State is located in the Northeastern part of Nigeria. It is one of the 16 local government areas of the State and covers an area of approximately 2,672 km2. It lies between longitude $9051^{\prime} \mathrm{E}$ and $9.850^{\circ} \mathrm{E}$ and latitude $8019^{\prime} \mathrm{N}$ and $8.317^{\circ} \mathrm{N}$. The Ibi town is located at the South Bank of Benue River. The Taraba and Donga rivers flow into the Benue within the local government area. The economy of this place is agriculturally based; catching fish from the Benue River and producing Crop of various types through utilization of the available land therein.

\subsection{Sampling Procedure and Data Collection}

Purposive sampling techniques was used to select respondents involved in purchasing catch and smoking fish before sales. Eighty (80) of the small-scale dealers selected make sales in the Ibi markets every week. Data were collected from respondents with the aid of questionnaire and interview. Primary data were used in this research work.

\subsection{Data Analytical Techniques}

Data collected were analyzed using descriptive statistics, value added and profitability analytical models. Descriptive statistics, including frequency counts, and percentages were used to achieve objectives (i), while objective (ii); (iv) and (v) were achieved using value added and gross margin analytical procedures among others; (iii) was achieved using Ordinary Least Squares (OLS) analytical procedure.

\subsubsection{Regression Analysis}

The explicit form of the regression model equation is as shown below:

$$
Y=b_{1} X_{1}+b_{2} X_{2}+b_{3} X_{3}+b_{4} X_{4}+b_{5} X_{5}+b_{6} X_{6}+\mu_{i}
$$

Where,

$\mathrm{Y}=$ Income of the marketers $(\mathrm{N})$

$\mathrm{X} 1=$ Age of marketers (years)

$\mathrm{X} 2=$ Gender

$\mathrm{X} 3$ = Marital status

$\mathrm{X} 4=$ Family size

$\mathrm{X} 5=$ Educational level

X6 $=$ Marketing experience

$=$ Error term

\subsubsection{Marketing Margin}

$$
M M=\frac{F S P-F P P}{F S P} * 100
$$

Where;

$M M=$ Marketing Margin of Fish

$F S P=$ Fish Selling Price, and 
$F P P=$ Fish Purchase Price.

\section{MAP OF IBI LOCAL GOVERNMENT AREA}

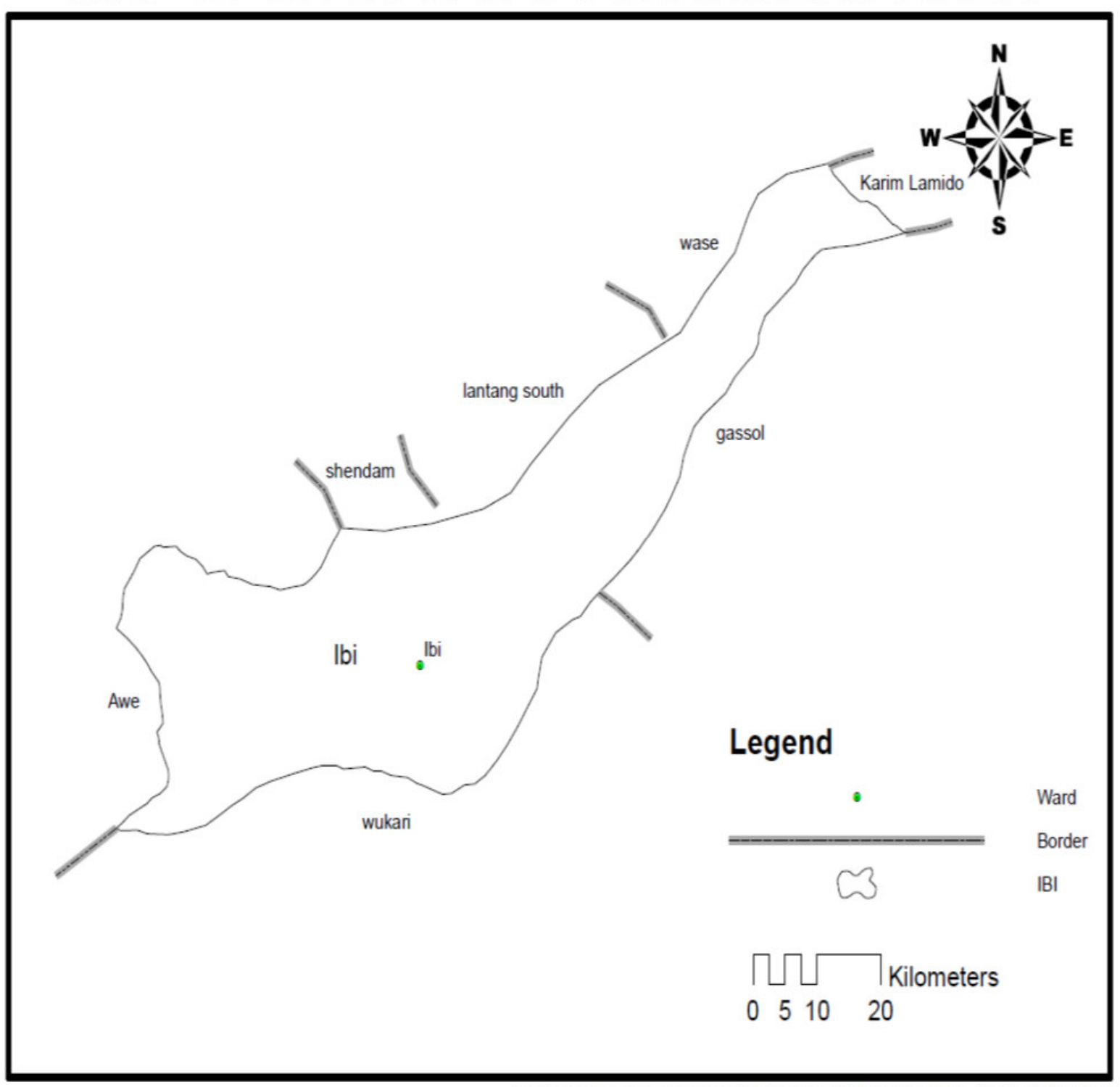

SOURCE: GEOGRAPHY DEPT, KWARARAFA UNI, WUKARI

Figure 1. The map of Ibi Local Government Area of Taraba State, Nigeria.

\subsubsection{Value Added Model}

Value addition through smoking of fish is a process of increasing the economic value and shelf life of the commodity. Value addition here refers to current price or cost of purchasing smoked-fish less price or cost of fresh fish at point of purchase and before processing (smoking/drying) form. This is expressed thus:-

$V_{A}=C_{C S F}-C_{C U F}$

(3)

Where; 
$V_{A}=$ Value Added (

$C_{C S F}=$ Cost or Current Market Price of Smoked/fire dried fish ( $)$

$C_{C_{U F}}=$ Cost of Unprocessed fish (Fresh fish) (\#)

\subsubsection{Fish Smoking Efficiency}

Efficiency is defined as the ability to produce something with a minimum amount of effort. An example of efficiency is a reduction in the amount of number of workers and costs needed to get fish smoked enough, preserve and sustain shelf life. Fire smoking is a major method adopted in preserving fish by marketers in the study area. Fish smoking efficiency is estimated by the following relation:-

$F_{S E}=\frac{V_{A S}}{C_{S S}} * 100$

Where;

$F_{S E}=$ Fish Smoking Efficiency

$V_{A S}=$ Value Added by Smoking

$C_{S S}=$ Cost of Smoking Service(s)

\subsubsection{Smoked-fish Marketing Efficiency Model}

Marketing efficiency is the ratio of output of marketing system (Value Added) to input used in marketing system (cost of marketing, excluding margins of market functionaries). The higher ratio denotes higher efficiency of produce marketed through a particular marketing channel. (https://www.google.com/search?q=marketing+efficiency)

$S F_{M E}=1+\frac{V_{A M}}{C_{M S}} * 100$

Where;

$S F_{M E}=$ Smoked-Fish Marketing Efficiency

$V_{A M}=$ Value Added by Marketing

$C_{M S}=$ Cost of Marketing Service(s)

Note: Smoking/fire-drying operations use fuel wood.

3.2.6 Profitability Model is given thus:-

$N M I=T M R-(T M V C+T M F C)$

Where;

$N M I=$ Net Marketing Income

$T M R=$ Total Marketing Revenue

$T M V C=$ Total Marketing Variable Costs

$T M F C=$ Total Marketing Fixed Costs

\section{Results and Discussions}

Descriptive statistics, marketing margin, net marketing margin and net return to marketing estimation procedures as well as regression analysis were used to determine the values of the profitability measures and influencing socio economic character of the smoker-marketers that infer the economic viability of fish smoking and marketing venture.

\subsection{Socio-economics Characteristics of the Marketers}

These are factors relating to or concerned with the interaction of social and economic factors. The varied dynamism of marketing activities among any group is best understood through the identification of the factors that constitute the route or means of access and success to a particular business. Socio-economic factors of any group or society are believed to have direct influence on the way forward or movement towards the destination and development of a business by the group members. Those involved in fish smoking and marketing business are no exceptions to this conventional influence of socio-economic characteristics. In this context, it is of key importance to throw light on their socio-economic characteristics. The Socio-economic characteristics of 
marketers examined include age, gender, marital status, household size, educational background and years of experience in the marketing of smoked-fish.

\subsubsection{Age of the Respondents}

Table 1 below shows the age range, frequency and percentage of the fish smoker-marketers studied. It can be deduced from the table that majority of the respondents are at their active and viable age required for economics activities. The people within the age group of 18-60 years are popularly referred to as active population or working population, Ande (2008). This group are regarded as the economic age bracket that is involved in productive activities. This situation is expected to enable translating to a high desire to increase family income, as is with Babalola et al. (2015)'s submission.

Table 1. Distribution of the Respondents by Age

\begin{tabular}{lccc}
\hline & Age Range & Frequency & Percentage (\%) \\
\hline & $18-26$ & 19 & 23.75 \\
$27-35$ & 27 & 33.75 \\
& $36-44$ & 10 & 12.50 \\
& $45-53$ & 15 & 18.75 \\
& $54-62$ & 6 & 7.50 \\
& 63 Above & 3 & 3.75 \\
\hline Total & & $\mathbf{8 0}$ & $\mathbf{1 0 0}$ \\
\hline
\end{tabular}

Source: Field survey 2017

\subsubsection{Gender of the Respondents}

Table 2 reveals that both males and females participate in smoking and marketing of fish, with the females taking the lead. This implies that household responsibilities associated with marriage such as child nurturing and upbringing among others, may affect the trading activities of the smoked fish marketers, given the dominance of women over men in the smoked fish marketing business. This is in line with (http://www.fao.org/docrep/s4863e/s4863e09.htm\#TopOfPage) the findings of Petra C. Spliethoff, where it was argued that Women traditionally have played a major role in the activities of handling, processing, and marketing of fish products as well as essential complementary functions of all food production systems.

Table 2: Distribution of the Respondents by Gender

\begin{tabular}{lcc}
\hline Gender & Frequency & Percentage (\%) \\
\hline Male & 10 & 12.50 \\
Female & 70 & 87.50 \\
Total & 80 & 100 \\
\hline
\end{tabular}

Source: Field survey, 2017

\subsubsection{Marital Status of the Respondents}

The status that exhibits legal relationship between people either as a husband or wife of the respondents in table 3 indicates that married people dominate smoked-fish marketing in the area. This may be due to the fact that they have numerous domestic responsibilities to meet up with, including feeding, payment of children school fees, health bills among others. This implies that responsibilities associated with marriage such as child nurturing and upbringing may affect the trading activities of the smoked fish marketers. Besides, respondents that are single and widowers account for less of the respondents.

Table 3: Distribution of Respondents by Marital Status

\begin{tabular}{lll}
\hline Marital status & Frequency & Percentage (\%) \\
\hline Single & 11 & 13.75 \\
Married & 65 & $\mathbf{8 1 . 2 5}$ \\
Widow (er) & 4 & 5 \\
Total & 80 & 100 \\
\hline
\end{tabular}

Source: Field survey 2017 


\subsubsection{Family Size of the Respondents}

Table 4 below reveals that the respondents' have household sizes ranging between 1-20 persons. The major reason being instances of polygamy and wives have to fend for themselves my engaging in fish smoking and marketing. A similar study in Adamawa state found the household sizes. However, family size range from 110 constituted $(71.25 \%)$, while the range of $11-20$ formed $(18.75 \%)$ with just few $(3.75 \%)$ having above 20 persons (Madugu and Edward, 2011).

Table 4: Distribution of Respondents by Family Size

\begin{tabular}{lll}
\hline Family size & Frequency & Percentage (\%) \\
\hline $1-10$ & 61 & 76.25 \\
$11-20$ & 19 & 23.75 \\
Total & 80 & 100 \\
\hline
\end{tabular}

Source: Field survey, 2017

\subsubsection{Major Occupation of the Respondents}

The distribution of the respondents by main occupation reveal majority to have taken up fish smoking and marketing as primary or sole occupation as depicted in table 5 below. Besides, more civil servants than general crop farmers are taking it as secondary or supporting/part time occupation, with major part of their time dedicated to their primary occupations. This implies that smoked fish marketing is the major occupation of higher proportion of the smoked fish marketers and can be attributed to the viability and profitability of the business. This may also be linked to the fact that fishing is the main occupation of most household heads in riverine communities of Ibi L.G.A of Taraba State.

Table 5: Distribution of Respondents by Major Occupations

\begin{tabular}{|l|l|l|}
\hline Major occupation & Frequency & Percentage (\%) \\
\hline Farming & $\mathbf{5}$ & $\mathbf{6 . 2 5}$ \\
Civil service & 6 & 7.50 \\
Fish Smoking \& marketing & 69 & $\mathbf{8 6 . 2 5}$ \\
Total & $\mathbf{8 0}$ & $\mathbf{1 0 0}$ \\
\hline
\end{tabular}

Source: Field survey, 2017

\subsubsection{Educational Level of Respondents}

Literacy level of the respondents show that majority have no formal education, while few spent up to 12 years as in a 6-3-3 system educational school (for primary and secondary schools). This implies that majority of the smoked fish marketers were non-literates with little or no formal education. A similar study by Babalola et al. (2015) also revealed that majority of the fish marketers in Ogun State who were mainly women had low level of education. This may also explain why most of them had opted for trading which requires little or no formal education. The distribution of the respondents by their educational levels is shown in table 6 below.

Table 6: Distribution of Respondents by their Level of Education

\begin{tabular}{lll}
\hline Educational background & Frequency & Percentage (\%) \\
\hline Non-formal education & 43 & 53.75 \\
Primary & 14 & 17.50 \\
Secondary & 20 & 25.00 \\
Tertiary & 3 & 3.75 \\
Total & 80 & 100 \\
\hline
\end{tabular}

Source: Field survey, 2017

4.1.7 Marketing Experience of the fish Marketers

Table 7 below reveals that the marketing experience of the respondents ranges from 1-46 years. The mode frequency marketing experience ranges between 1-15 years, while $02.5 \%$ have marketing experience of 46 
years and above. A similar study by Madugu and Edward (2011), found marketers with experience of between 11-20 years and $21-30$ years constituting about $30 \%$ and $28.75 \%$ of their total study population, respectively. The two studies shows that most smoked fish marketers have experience ranging from 1-30 years.

Table 7: Distribution of Respondents by Marketing Experience

\begin{tabular}{llll}
\hline Marketing Experience & (Years) & Frequency & Percentage (\%) \\
\hline $1-15$ & & 44 & 55.00 \\
$16-30$ & 27 & 33.75 \\
$31-45$ & 7 & 8.75 \\
46 Above & 2 & 2.50 \\
Total & 80 & 100 \\
\hline
\end{tabular}

Source: Field survey, 2017

\subsubsection{Distribution of Respondents according to Preservation Method Adopted}

The frequency distribution of respondents according to preservation method adopted reveals that majority (78.75\%) used smoking method of extending the shelf life of the fish purchased. Sun-drying accounts for $18.75 \%$ of the respondents, but oven drying accounted for less $02.5 \%$. This finding is in line with the study of Traditional fish processing in Nigeria: A critical review by S. A. O. Adeyeye (2016), where it was asserted that fish smoking still remains the main method of fish preservation in Nigeria as over 70 per cent of the catch is smoked; though, observed that quality of smoked fish from Nigeria has been found to be within acceptable quality limits specific by various regulatory agencies. However, findings have revealed microbial contamination and the presence of polycyclic aromatic hydrocarbons in some of the smoked fish which values exceed the EU recommended maximum permissible level of $5.0 \mu \mathrm{g} / \mathrm{kg}$ for benzo[ $\alpha]$ pyrene.

Table 8: Frequency Distribution of Respondents according to Preservation Method Adopted

\begin{tabular}{|l|r|r|r|}
\hline Preservation Method & Frequency & Percentage Adopters \\
\hline Freezing & 0 & 0 & 18.75 \\
\hline Sun-drying & 15 & 2.5 & \\
\hline Oven-drying & 2 & 0 & \\
\hline Fermentation & 0 & 0 & \\
\hline Heat Treatment & 0 & 0 & \\
\hline Pasturization & 0 & 78.75 & \\
\hline Smoking & 63 & & \\
\hline
\end{tabular}

Source: Field Survey, 2017

4.2 Effects of Socio-Economic Characteristics of Smoked Fish Marketers on their Income

In the analysis of the effects socio-economic characteristics of smoked fish on their income, Ordinary Least Square (OLS) was used. The dependent variable (Y) was income of the smoked fish marketers; while the explanatory variables were (Xs) which age of fish marketers, gender, marital status, household size, major occupation, educational level marketing experience and preservation method adopted. The result of the regression analysis is as presented below: -

Table 9: Ordinary Least Square (OLS) Regression Coefficients; t-value, Standard Errors, and Level of Significance of six (6) predictor Variables Relate to Income Level

\begin{tabular}{llll}
\hline Variables & Regression Coefficients & Standard Errors & Level of significance \\
\hline $\mathbf{X}_{\mathbf{1}}=$ Age & 0.960 & 4608.702 & 0.017 \\
$\mathbf{X}_{\mathbf{2}}=$ Gender & 0.186 & 73235.496 & 0.218 \\
$\mathbf{X}_{\mathbf{3}}=$ Marital Status & -0.114 & 41707.730 & 0.398 \\
$\mathbf{X}_{\mathbf{4}}=$ Household size & -0.056 & 10265.580 & 0.780 \\
$\mathbf{X}_{\mathbf{5}}=$ Experience & -0.304 & 6743.939 & 0.311 \\
$\mathbf{X}_{\mathbf{6}}=$ Education & 0.220 & 6108.895 & 0.020 \\
\hline
\end{tabular}

Source: Field Survey, 2017. Adjusted $\mathrm{R}^{2}=0.668 ; \mathrm{F}=27.798$ 
Table 10: Model Summary

\begin{tabular}{lllll}
\hline Model & R & R-Squared & Adjusted R Square & $\begin{array}{l}\text { Std. Error of the } \\
\text { Estimate }\end{array}$ \\
\hline $\mathbf{1}$ & $.832^{\mathrm{a}}$ & .693 & .668 & 263402.449 \\
\hline
\end{tabular}

Source: Field survey, 2017

Considering the estimated regression equation: $\mathrm{Y}=0.960 \mathrm{X}_{1}+0.220 \mathrm{X}_{6}$

Where; $\mathrm{Y}=$ Income of fish smoked fish marketers; $X_{1}=$ Age; while $X_{6}=$ educational level, the estimated values of $\mathrm{Y}$ can be obtained by substituting the corresponding observed values of the significant explanatory variables in the estimated equation line above.

The regression coefficients $\hat{b}_{1}=0.960$ and $\hat{b}_{6}=0.220$ show positive influence of age and education on the income of the smoked fish marketers in the study area. This implies that, for any additional increase in age or educational level, the income of the marketers would increase by 0.96 and 0.22 units in their income, respectively. Besides, with an R-squared of $69.3 \%$ and an adjusted $\mathrm{R}^{2}$ is $66.8 \%$, yielding an average of $68.05 \%$, it means that the independent variables explained up to $68.05 \%$ of the variability in the value of the dependent variable Y.(income).

Age $\left(\mathbf{X}_{1}\right)$ : As shown in table 8 above, the coefficient of this variable is 0.960 . The standard error is 4608.702 , which is significant at $5 \%$ level of significance. It has a positive relation with the income of the smoked fish marketers; this means that as respondents' age increases, income increases.

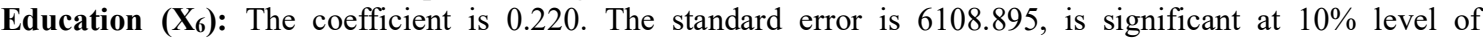
significance. The relationship is positive which means that as educational level increases the income level increases.

Decision rule: From the table above, the Fcal is 27.798 which is greater than Ftab which is 2.29. Therefore, the null hypothesis "The socio-economic characteristics of smoked fish smoked fish marketers do not significantly influence their income" is rejected, and the alternative hypothesis "The socio-economic characteristics of smoked fish smoked fish marketers significantly influence their income" accepted. This is because age and education has been found to influence the income level of the fish marketers in the study area.

\subsection{Profitability of Fish Smoking and Marketing}

Table 9 below presents the profitability estimated values of fish smoking and marketing. The estimated values include the total revenue, total cost, and value added by smoking; net revenue, percentage marketing margin and percentage net marketing margin.

Table 11: Profitability of Smoking and Marketing of Fish

\begin{tabular}{|l|l|}
\hline Item & Estimated Values \\
\hline Unprocessed Fish Purchase Price & $56,340.00$ \\
\hline Total Smoked Fish Sales Revenue & $73,576.00$ \\
\hline Total Marketing Cost & $57,802.00$ \\
\hline Value Added by Smoking & $10,133.00$ \\
\hline Weekly Net Revenue & $23.43 \%$ \\
\hline Marketing Margin & $13.77 \%$ \\
\hline Net Marketing Margin & 3.059 \\
\hline Fish Smoking Efficiency & 2.426 \\
\hline Smoked Fish Marketing Efficiency & \\
\hline
\end{tabular}

Source: Estimated from field Survey, 2017.

The fish smoking efficiency of 3.06 and smoked fish marketing efficiency of 2.43 indicates that the dealers make a net return of 3.06 times per $\$ 1.00$ invested in fish smoking which sells 2.43 times faster than unsmoked type. Hence, a clear indication that fish smoking and marketing is economically viable in the area studied.

\section{Conclusion and Recommendations}

The socio-economic characteristics that influence fish smoking and marketing include age and education, though it is a worthwhile agribusiness venture that can be embarked upon given the estimated marketing margin, net marketing Margin, fish smoking efficiency and smoked fish marketing efficiency? It is recommended that:-

(i) Due to positive influence education has on marketers' income, it is recommended they should endeavor to 
improve on their educational level by attending night schools.

(ii) National market development and coordination should put in place to ensure the adoption of and the use of standard weight and measure for fish smoking and marketing in the area.

(iii) Cost saving transportation and smoking service facilities should be sustained by private individuals and corporate groups alike to improve efficiency of venture by dealers.

(iv) Capacity building for agricultural extension officers and enumerators on market information service (MIS) should be intensified by Government.

(v) Marketers should be encouraged to diversify their economic activities so as to get supplementary income to improve standard of living.

Acknowledgement: The authors appreciate the Federal University Wukari Institutional Based Research Commiittee of Department of Agricultural Economics and Extension Services for its inputs which has added value to this manuscript.

\section{REFERENCES}

Abah D., D. Zaknayiba and E. Simon (2013). Economic Analysis of fish marketing in Lafia Local Government Area of Nasarawa State, Nigeria. Production Agriculture and Technology Journal 9 (2): 54-62 ISSN: 0794-5213.

Acharya S. S., \&Agarwal N.L (2001). "Agricultural marketing in India”. Oxford and IBH Publishing Company PVT Ltd. Delhi

Afigbo, A. E. (1997). "Southeastern Nigeria, the Niger-Benue Confluence, and the Benue in the Pre-colonial Period": Some Issues of Historiography"History in Africa 24: pp. 1-8, p.4

Akinola Babalola, O. Bajimi and S.U Isitor (2015). Economic potentials of fish marketing and women empowerment in Nigeria. African Journal of Food, Agriculture, Nutrition and Development. Vol. 15 No. 2. Published by African Scholarly Science communication Trust.

Amos, T., \& Bolorunduro, P. (2000). Economics of aquaculture production. Zaria: National Agricultural Extension and Research Liasson Services (NAERLS).

Bagchi, M. \&Raha, S.K. (2011) Post Harvest Loss of Flower and its Impacts on Flower Marketing in Bangladesh. Journal of Economic Affairs, 2(56), 205-211

Benjamin Chijoke Asogwa and Victoria Ada Okwoche (2012). Marketing of Agricultural Produce among Rural Farm Households in Nigeria: The case of Sorghum Marketing in Benue State. International Journal of Business and Social Science, vol. 3 No.13

Cramer G.L, Jensen W (1982). Agricultural Economics and Agribusiness, 2nd Edition. McGraw Hill Book Company, USA. $222 \mathrm{p}$.

Eyo A.A (2008). Utilization of fresh water species in Nigeria. Proceeding of Annual Conference of the Fisheries Society of Nigeria.

Eze, S. O., A. N. Ezeh and E. A. Onwubuya (2010). Women marketers' perceived constraints on selected agricultural produce marketing in Enugu South Local Government Area: challenges of extension training for women groups in Enugu State, Nigeria. Agroscience Journal of Tropical Agriculture, Food, Environment and Extension, 9(3): 215-222.

FAO (2013). FAO Country Programming Framework (CPF) Federal Republic of Nigeria; 2013-2017 projection.

Fishery Committee for the West Central Gulf of Guinea, FCWC (2016). Nigeria fishery Statistics - 2016 Summary report. Retrieved from http://www.fcwcfish.org/fisheries/statistics/nigeria

https://www.meat-machinery.com/meat-processing-insight/Nigerian-smoked-fish-market-potential.html Retrieved, December, 2018.

https://www.investopedia.com/terms/n/net_margin.asp Retrieved, August, 2018.

https://www.woccu.org/documents/Tool6 Retrieved, November, 2018.

https://www.investopedia.com/terms/e/efficientmarkethypothesis.asp Retrieved, July, 2018.

http://ecoursesonline.iasri.res.in/mod/page/view.php?id=16979 Retrieved, July, 2018.

http://www.fao.org/docrep/s4863e/s4863e09.htm\#TopOfPage Retrieved December, 2018.

ICSF (2002). "Report of the problems and Prospect of Artisanal Fish Trade in West Africa". International Collective in Support of Fish workers.

Ikenwa Stephen Chukwudalu (2016). Economic Analysis of Fresh fish Marketing for selected markets in Girei Local Government Area of Adamawa State. Unpublished.

James O. Bukenya, T. H. (2012). Economics of Fish Marketing in Central Uganda: A Preliminary Analysis. Researchgate, pp. $1-25$.

Kainga, E. and Adeyemo, A.O. (2012). Socioeconomics characteristics of fish marketers inYenagoa Local Government Area of Bayelsa State, Nigeria. World Journal of Young Researchers. 2(1): 22-31. 
Kamthorn Potongkam and Jim Miller (2006)." Manual on catfish hatchery and production: A guide for small-scale to medium-scale hatchery and farm producers in Nigeria". Aquaculture and Inland Fisheries project.

Kohls, Richard L. and Uhl Joseph N (1980). "Marketing of agricultural products". Macmillan; London: Collier Macmillan, New York

Lampkin N. (2001). "Organic Farm Management Handbook, Organic Farming Research Unit,Institute of Rural Studies, University of Wales". Aberystwyth, Newbury: Organic Advisory Services, Elm Farm Research Centre.

Lawal, W.L and Idega, E.O. (2004): Analysis of fish marketing in Benue State. Proceedings of the 2004 Annual Conference of the National Association of Agricultural Economists (NAAE) held at ABU Zaria, Nov 3rd -5th, 2004

Lawrence Olusola Oparinde and Sylvester Oluwadare Ojo (2014).Structural Performance of Artisanal Fish Marketing in Ondo State, Nigeria. American Journal of Rural Development, 2014, Vol. 2, No. 1, 1-7 Available online at http://pubs.sciepub.com/ajrd/2/1/1

Lou E. Pelton David Strutton and James R. Lumpkin (2016). "Marketing Channels: A relationship management approach". U.K: McGraw-Hill Companies, Inc.

Madugu, A. L. and A. Edward (2011) Marketing and distribution channel of processed fish in Adamawa State, Nigeria: Global Journal of Management and Business Research, 11(4): 21-26.

Margarita Isoraite (2009). "The theoretical aspect of marketing strategy". Mykolas Romeris University publication. Pg 114125

Marius Ludicke (2006). "A theory of marketing: Outline of a social systems perspective". DUV, Gabler Edition Wissenchaft.

Mendoza M, Rosegant M (1995). Pricing conduct of spatially differentiated markets. Prices, Products, and People. International Potato Center, Lima, Peru. Pp.343-356.

Naoki et al (2013). Fisheries in Nigeria: Report to the Ministry of Agriculture, Nigerian Government.

Nsikan Edet Bassey et'al (2014). Analysis of the Determinants of Fresh Fish Marketing and Profitability among Captured Fish Traders in South-South Nigeria: The Case of AkwaIbom State. British Journal of Economics, Management and Trade. No. BJEMT.2015.003

Nwabueze, A. A. and E. O. Nwabueze (2010). An investigation into the problems of fresh fish marketing in Oshimili South Local Government of Delta State, Nigeria; Agricultural and biological journal of North America.2(2) 23-35.

Nwabunike M.O. (2015). Socio-economic Characteristics of Fish Marketers in ABakaliki Metropolis of Ebonyi State. International Journal of Animal Health and Livestock Production. Vol.1, No.1, pp.28-36, June 2015

Nwankwo S. and Ogalue I.R (2000). An assessment of Processing and Marketing in Owerri Urban of Imo State, Nigeria. Journal of Agriculture and Social Sciences ISSN Print; 1597-1074; ISSN Online 47-52 http://www.fspublisher.org

Okoronkwo, Victor Ugochukwu (2016). Analysis of women retailers and smoked fish marketers participation in fish marketing in Ebonyi north, Nigeria. An M.sc dissertation presented to the department of agricultural economics and extension, faculty of agriculture, Abia State University, Uturu.

Ozigbo Emmanuel (2014). Review of Aquaculture Production and Management in Nigeria: American Journal of Experimental Agriculture 4(10): 1137-1151.

S. A. O. Adeyeye (2016). Traditional fish processing in Nigeria: A critical review. Available from: https://www.researchgate.net/publication/294090630_Traditional_fish_processing_in_Nigeria_A_critical_review [accessed Dec 22 2018].

Subba S. Reddy et'al (2014). “Agricultural Economics”. Oxford \& IBH publishing company pvt. Ltd. New Delhi.

Swaroop Rout (2015). What are the functions of a wholesaler? Publish Your Article. Retrieved from http://www.publishyourarticles.net/knowledge-hub/business-studies/what-are-the-functions-of-wholesaler/779/

Tomek WG,

Robinson KL (1990). Agricultural Product Prices. Third ed., Cornell University Press, New York. Pp.107-8(360)

Umoinyang Nfon E (2014). Economics of Fish Marketing In AkwaIbom State, Nigeria. A dissertation submitted to the department of Agricultural Economics, University of Nigeria, Nsukka.

Uzoagulu, A. E. (2011). "Practical Guide to writing Research project Reports in tertiary Institutions". : Cheston Ltd. Uwani, Enugu, Nigeria. Pp 171-174. 